\title{
Finding an influential voice for academies in Africa
}

AUTHOR:

Robin M. Crewe ${ }^{1}$ iD

\section{AFFILIATION:}

${ }^{1}$ Centre for the Advancement of Scholarship, University of Pretoria, Pretoria, South Africa

\section{CORRESPONDENCE TO:} Robin Crewe

EMAIL:

Robin.Crewe@up.ac.za

\section{KEYWORDS:}

ASSAf; IAP; NASAC; advisory role; evidence-informed policy

\section{HOW TO CITE:}

Crewe RM. Finding an influential voice for academies in Africa. S Afr J Sci. 2016;112(9/10), Art. \#a0175, 2 pages. http://dx.doi. org/10.17159/sajs.2016/a0175

(C) 2016. The Author(s). Published under a Creative Commons Attribution Licence.
Scholarly academies have been in existence for about 350 years, with the oldest being those that were established in Europe in the 17th century. These institutions consist of groups of individuals who are elected by their peers to be members (often called fellows); since the middle of the 19th century, election to the august ranks of most academies has been based on recognition of the outstanding scholarly work done by those proposed for membership. Academies have made the transition from being learned societies to being select groups of eminent scholars who are often widely admired in their countries.

The transformation of academies into institutions that have the most eminent scholars of a nation as their members, meant that they became influential in advising their national governments and were regarded as a unique source of expert advice in matters of national concern. However, this has not always been the case in the history of European academies and often is not the case for more recently established academies in other parts of the world, particularly in Africa. Lorna Casselton, a former Foreign Secretary of the Royal Society of London pointed out somewhat acerbically, 'My post was instituted in 1723, nearly 60 years before the British government appointed its first Secretary of State for Foreign Affairs', making the point that academies were transnational in their reach long before governments formally established offices to deal with international relations. Academies engage with a global community of scholars whose interests are aligned primarily with their disciplines and only secondarily with their national origins. Governments have often been slow in understanding the value that academies have in providing advice. A good example of this is the publication by the Academy of Science of South Africa (ASSAf) of the report HIVIAIDS, TB and Nutrition (2007) which, although not accepted initially, had a significant impact through providing a basis for a radical change in national policy for the treatment of HIV/AIDS.

The use of independent academies to provide advice on matters of public interest is of significant benefit to governments when they are confronting difficult political and technological choices. However, the degree to which this advice is solicited and then subsequently used depends on the nature of the government in place and their assessment of the political risks associated with accepting independent, impartial advice.

With the exception of the US National Academies of Science (USNAS) that was established by Abraham Lincoln to offer advice to Congress on matters of science and technology, most academies started out their lives as learned societies that were largely honorific in their function. The rigour with which their members are chosen, meant that there was significant prestige associated with election to these bodies. However, academies did not conceive of themselves as reviewing matters of national importance based on the best available evidence with a view to providing informed insights for policy development by governments. This latter role has developed and accelerated over the course of the 20th century, as technological advances and growth of human populations have placed increasing strain on natural resources, thereby requiring governments to make policy choices in relation to highly technical matters. The range of expertise that academies can bring to bear on the assessment of these problems through their membership is unique and valuable, if appropriately used.

The key element that makes academies valuable as sources of multi-perspective advice is their independence in two important respects - they are governed by councils that are elected by their members and they have a professional secretariat appointed by their councils.

As a subset of the global family of academies has re-conceptualised their role as outlined above, they have realised the necessity to establish networks of academies in order to address issues that are of regional or global concern. The InterAcademy Panel (now IAP for Science) that is the global network of science academies was established in 1993 in order to assist with the coordination of the activities of national academies on a global scale. It now has 107 member academies and plays an important coordinating role in matters that are of global concern by convening meetings of its member academies and by facilitating the establishment of regional academy networks to deal with specific matters at a regional level.

In the case of Africa, although some academies have been in existence for over a century, most have a much shorter history associated with the timing of their country's liberation from their colonial governments. Conceptualising a role beyond the honorific one by these academies has been a recent phenomenon that is still in the process of being formally established.

A successful advisory role for academies is dependent on three conditions: they need to be seen as offering independent advice which is not partisan, they need to have well-established methodologies for providing advice that is robust and establishes confidence in the reports that are produced and, finally, they need to have a government and civil society that is potentially receptive to the advice.

Based on this short exploration of the history of academies, I can now turn to ASSAf - the Academy of Science of South Africa - and put its development in the context that I have sketched. ASSAf was inaugurated in 1996 at a gala dinner hosted by then President Nelson Mandela who acted as the patron of this newly established academy. The key point about the launch of ASSAf was that it conceptualised itself ab initio in a way that was not common for academies - it had the traditional role of honouring those who were elected to its membership, but it also defined for itself an activist role of using science for the benefit of society.

Between 1996 and 2001, the Members of ASSAf were in discussion with the officials of the Department of Science and Technology (DST), actually the Department of Arts, Culture, Science and Technology at the time, to get an Act passed by parliament to establish ASSAf as a statutory body. This was finally done in 2001 and ASSAf came into being as the national academy of science in May 2002. During this period, ASSAf was largely pursuing the honorific 
role that was the key element that gives academies their strength and their substance - the expertise and standing of their members.

With the establishment of ASSAf as a statutory body, it entered a new phase of development during which a professional secretariat was established and an executive officer appointed. The first Executive Officer, Prof. Wieland Gevers, was instrumental in giving ASSAf an institutional identity through the writing of the regulations that govern its activities and in giving substance to the work of the secretariat. Indeed, he translated the activist aspirations of this nascent academy into action through the initiation of the first study that ASSAf undertook: Report on a Strategic Approach to Research Publishing in South Africa. This report was commissioned by DST, and when completed was welcomed both by that department and the Department of Higher Education and Training (DHET) because its recommendations provided a basis for quality assurance of journals published in South Africa and provided DHET with recommendations for a more reliable basis for evaluating the research publications produced by universities.

ASSAf's ability to have an impact in influencing government policy was given a very significant boost through being one of the academies included in the African Science Academies Development Initiative (ASADI) that was initiated by USNAS with funding from the Bill \& Melinda Gates Foundation. The programme provided funding for 5 years and also involved intensive mentoring of the staff of the ASSAf secretariat by the staff of USNAS. During this period, the way in which ASSAf provided advice to government and other organisations, evolved to the point at which a range of instruments was deployed to provide advice in different situations.

The other important element of the ASADI programme was that its annual meetings provided a platform for the expansion of the Network of African Academies of Science (NASAC) that was established in 2001 with ASSAf as one of the founding nine members. At the conclusion of the ASADI programme in 2015, NASAC had grown to include 21 African academies of science and had instituted a range of programmes that fostered both academy development and the collaboration of member academies in a range of studies including addressing the issues of the use of scarce water resources and maternal and child health.

The real challenge facing NASAC and its member academies is the way in which they will be able to influence governments in Africa and the panAfrican organisation, the African Union (AU), to address the Sustainable Development Goals and achieve the AU Commission's Agenda 2063 aspirations. Up to this point, their role in these discussions has not been central, but they will need to conceptualise ways in which they will be able to achieve a much greater level of influence over the coming decade because ambitious targets - 'no poverty' and 'zero hunger' - have already been set for 2030 .

Working in their own national environments and collectively as members of NASAC (the affiliate network of the IAP for Africa), the African academies of science will need to generate a set of credible interventions and recommendations that will assist governments and the $\mathrm{AU}$ to achieve their goals. Goal setting of this kind can be depressing if the goals are not achieved, but the achievement of the goals would lead to a level of wellbeing in the countries involved that would be its own reward.

At the beginning of this piece, I posited three requirements for a modern academy to be successful: the first was that the advice should be seen to be impartial, the second was that the academy should have an armoury of instruments that could be used to generate advice and the third was a government and civil society that was receptive of advice. I believe that the first two requirements are already in place for most of the African academies of science thanks to their participation in the activities of NASAC. The third remains somewhat problematic, as this is an area in which the academies and their members need to use their influence in order to ensure that their recommendations and statements are taken seriously. This can only be achieved by an ongoing engagement with the individuals and institutions that need to be influenced - ensuring that the voice of the academies is heard not only in the national context, but also on regional and continental scales. 